\title{
Parachlamydia acanthamoebae Detected during a Pneumonia Outbreak in Southeastern Finland, in 2017-2018
}

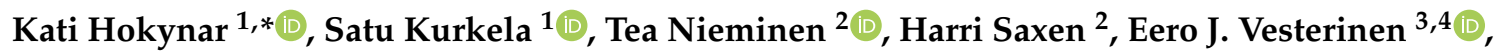 \\ Laura Mannonen ${ }^{1}$, Risto Pietikäinen ${ }^{5}$ and Mirja Puolakkainen ${ }^{1}$ (D) \\ 1 Department of Virology, University of Helsinki and Helsinki University Hospital, FI-00014 Helsinki, Finland; \\ Satu.Kurkela@helsinki.fi (S.K.); Laura.Mannonen@hus.fi (L.M.); Mirja.Puolakkainen@helsinki.fi (M.P.) \\ 2 Children's Hospital, University of Helsinki, FI-00029 Helsinki, Finland; tea.nieminen@hus.fi (T.N.); \\ harri.saxen@helsinki.fi (H.S.) \\ 3 Department of Ecology, Swedish University of Agricultural Sciences, SE-75007 Uppsala, Sweden; \\ ejvest@utu.fi \\ 4 Biodiversity Unit, University of Turku, FI-20014 Turku, Finland \\ 5 Department of Internal Medicine, Kymenlaakso Central Hospital, FI-48210 Kotka, Finland; \\ Risto.Pietikainen@kymsote.fi \\ * Correspondence: kati.hokynar@helsinki.fi
}

Received: 18 April 2019; Accepted: 14 May 2019; Published: 17 May 2019

check for updates

\begin{abstract}
Community-acquired pneumonia (CAP) is a common disease responsible for significant morbidity and mortality. However, the definite etiology of CAP often remains unresolved, suggesting that unknown agents of pneumonia remain to be identified. The recently discovered members of the order Chlamydiales, Chlamydia-related bacteria (CRB), are considered as possible emerging agents of CAP. Parachlamydia acanthamoebae is the most studied candidate. It survives and replicates inside free-living amoeba, which it might potentially use as a vehicle to infect animals and humans. A Mycoplasma pneumoniae outbreak was observed in Kymenlaakso region in Southeastern Finland during August 2017-January 2018. We determined the occurrence of Chlamydiales bacteria and their natural host, free-living amoeba in respiratory specimens collected during this outbreak with molecular methods. Altogether, 22/278 (7.9\%) of the samples contained Chlamydiales DNA. By sequence analysis, majority of the CRBs detected were members of the Parachlamydiaceae family. Amoebal DNA was not detected within the sample material. Our study further proposes that Parachlamydiaceae could be a potential agent causing atypical CAP in children and adolescents.
\end{abstract}

Keywords: Chlamydia-related bacteria; Parachlamydia acanthamoebae; Chlamydia pneumoniae; pneumonia; respiratory tract infections; disease outbreak; nucleic acid amplification test

\section{Introduction}

Community-acquired pneumonia (CAP) is a common disease responsible for significant morbidity and mortality. A variety of micro-organisms, including bacteria and viruses, can cause CAP. The most common bacterial pathogen in typical (sudden-onset) CAP is Streptococcus pneumoniae. The more slowly developing atypical CAP presenting often with extrapulmonary symptoms can be caused by Mycoplasma pneumoniae, Chlamydia pneumoniae, Legionella pneumophila, or viruses. Despite recent advances in microbiological techniques, the definite etiology of CAP often remains unresolved.

Chlamydia pneumoniae belongs to the Chlamydiaceae family within the order Chlamydiales, a group of obligate intracellular bacteria featuring a biphasic developmental cycle. Chlamydiaceae contains also well-known veterinary pathogens Chlamydia psittaci and Chlamydia pecorum that are known to be 
zoonotically transmitted to humans from infected animals (birds and livestock, respectively) and can cause pneumonia. In addition to Chlamydiaceae, the order Chlamydiales contains a wide and evolving set of novel bacteria, recently suggested to be taxonomically classified in 13 additional families within the order and collectively called Chlamydia-related bacteria (CRB) [1]. Many of the Chlamydia-related bacteria naturally reside in free-living amoeba, and CRB have been detected in a wide variety of environmental samples such as water and soil [2], but also in a wide range of animals, insects and arthropods [3]. Several of the CRBs have been suggested to cause respiratory disease and pneumonia in humans. The role of Parachlamydia acanthamoebae as an agent of pneumonia is most studied and many of the modified Koch's postulates are fulfilled. For instance, the pathogenicity is suggested by sero-epidemiological and molecular studies as well as by an experimental pneumonia model including a treatment trial [4,5]. Waddlia chondrophila is mainly associated with tubal factor infertility [6] and adverse pregnancy outcome [7], but also with lower respiratory tract infections [4,8,9]. In some reports, Simkania negevensis and Rhabdochlamydia spp. are detected in association with respiratory infections [10-12]. In our previous study, Rhabdochlamydia spp. DNA was detected in $12 \%$ of respiratory specimens from Finnish patients with respiratory tract infection [11].

A M. pneumoniae outbreak was observed in Kymenlaakso region in Southeastern Finland during August 2017-January 2018 [13]. The aim of this study was to study occurrence of Chlamydiales bacteria in respiratory specimens collected during this outbreak with molecular methods targeting the Chlamydia-related bacteria and their natural host, free-living amoeba.

\section{Materials and Methods}

\subsection{Respiratory Tract Samples}

The respiratory swab samples analysed in this study were collected during a M. pneumoniae outbreak observed in Kymenlaakso region in Southeastern Finland during August 2017-January 2018 (as described in detail in [13]). Respiratory tract swab specimens were available from two groups, from a total of 278 individuals. The first group contained 96 individuals who sought publicly funded healthcare consultation at local GPs or hospitals in the Kymenlaakso region and who were subsequently tested for M. pneumoniae nucleic acid between 1 August 2017 and 31 January 2018. The second group contained 182 individuals who participated in school screening arranged in four schools in the same area (Virolahti Middle School, Virojoki School, Virolahti High Shool and Klamila School, in Kymenlaakso region, Southeastern Finland). To collect information on their symptoms, individuals in the second group were asked to fill in a questionnaire. According to the survey, 112 had respiratory symptoms and/or fever, 15 did not report such symptoms, and from 55 individuals the information was not available.

\subsection{DNA Extraction}

DNA was extracted from respiratory specimens using MagNA Pure LC Total Nucleic Acid Isolation Kit (Roche Diagnostics GmbH, Mannheim, Germany). In detail, $300 \mu \mathrm{L}$ of specimen was lysed with $300 \mu \mathrm{L}$ of MagNA Pure Lysis/Binding Buffer (Roche Diagnostics GmbH, Mannheim, Germany). Five hundred $\mu \mathrm{L}$ (MagNA Pure LC) of specimen lysate was extracted with the MagNA Pure LC and eluted in $50 \mu \mathrm{L}$ of the elution buffer.

\subsection{Detection of Chlamydia pneumoniae}

A multiplex real-time PCR assay for simultaneous detection of M. pneumoniae, Chlamydia pneumoniae and mutations associated with macrolide resistance in Mycoplasma pneumoniae 23S rRNA gene along with an internal control developed by us [14] was used (Table 1). This assay amplifies C. pneumoniae ompA gene [15], and the analytical sensitivity (limit of detection with $95 \%$ probability) was 0.13 IFU/PCR reaction [14]. 


\subsection{PanChlamydiales-PCR}

Specimens were screened with a Chlamydiales-specific amplification method (PanChlamydialesPCR) as described earlier by Lienard et al. 2011 [16], with slight modifications [17] (Table 1.). This PCR method amplifies a 200-bp fragment of the 16S rRNA gene and has been shown to detect a wide range (at least all 15 chlamydial reference strains tested) of different members of the Chlamydiales order. A PCR mixture of $25 \mu \mathrm{L}$ contained $12.5 \mu \mathrm{L}$ Maxima Probe/ROX qPCR master mix (2X) (Thermo Fisher Scientific, Waltham, MA, USA), $100 \mathrm{nM}$ primers panCh-Fwd and panCh-Rev, and $100 \mathrm{nM}$ panCh-Probe (Table 1). The primers and probe were purchased from Integrated DNA Technologies. Amplification was performed with a 7500 Real Time PCR system (Applied Biosystems, Foster City, CA, USA Negative (water as extraction control and PCR reaction without template) and positive (DNA extracted from Simkania negevensis VR-1471) controls were included in each amplification run.

Extreme precautions were taken to avoid contamination in PCR. DNA extraction and preparation of PCR reaction mixes were conducted in separate laboratories with separate equipment, dedicated to pre-PCR activities only. In each run, 2 wells of PCR mix only were included as negative controls and 8 wells were used as nucleic acid extraction negative controls. Cycling conditions were $10 \mathrm{~min}$ at $95{ }^{\circ} \mathrm{C}$, followed by 45 cycles of $15 \mathrm{~s}$ at $95{ }^{\circ} \mathrm{C}$ and $60 \mathrm{~s}$ at $60^{\circ} \mathrm{C}$, all carried out in an Applied Biosystems ${ }^{\circledR} 7500$ Real-Time PCR System (Applied Biosystems, Foster City, CA, USA). All samples were tested in duplicate. Amplicons were sequenced. Samples with $\mathrm{Ct} \leq 37$ or with $\mathrm{Ct} 37-40$ and a Chlamydiales family levels sequence ( $>90 \%$ similarity with established Chlamydiales sequence [18]) were considered positive.

Table 1. Primers and probes used in this study.

\begin{tabular}{|c|c|c|c|}
\hline Target & Primer/Probe & Sequence & Reference \\
\hline \multirow{3}{*}{$\begin{array}{c}\text { M. pneumoniae } \\
\text { Hypothetical protein } \\
\text { C985_0367 }\end{array}$} & MP Fw & ATGTACTATCAGCAAAAGCTCAGTATGG & \multirow[t]{3}{*}{ [14] } \\
\hline & MP Rev & CCACATACCGCTTTAAGTTAGCAA & \\
\hline & MP probe & $\begin{array}{l}\text { Cy5-CTAACCAAAACAGCCCTTCAACGGCA-Iowa black } \\
\text { RQ-Sp }\end{array}$ & \\
\hline \multirow{3}{*}{ C. pneumoniae ompA } & $\mathrm{CP} \mathrm{Fw}$ & AAGGGCTATAAAGGCGTTGCT & \multirow[t]{3}{*}[14,15]{} \\
\hline & CP Rev & TGGTCGCAGACTTTGTTCCA & \\
\hline & $\mathrm{CP}$ probe & Tx Red-TCCCCTTGCCAACAGACGCTGG-Iowa black RQ-Sp & \\
\hline \multirow{3}{*}{$\begin{array}{l}\text { Homo sapiens } \\
\text { beta-globin chain }\end{array}$} & BG Fw & GGTTGGGATAAGGCTGGATTATT & \multirow[t]{3}{*}{ [14] } \\
\hline & BG Rev & CAGGAGCTGTGGGAGGAAGA & \\
\hline & BG Probe & $\begin{array}{l}\text { JOE/ZEN-CAAGCTAGGCCCTTTTGCTAATCATGTTCA-Iowa } \\
\text { black FQ }\end{array}$ & \\
\hline \multirow{3}{*}{$\begin{array}{l}\text { M. pneumoniae gene } \\
\text { for } 23 \mathrm{~S} \text { rRNA }\end{array}$} & MR-MP FW & GCTATAGACTCGGTGAAATCCAGG & \multirow[t]{3}{*}{ [14] } \\
\hline & MR-MP Rev & GCTACAGTAAAGCTTCACTGGGTC & \\
\hline & MR-MP SimpleProbe ${ }^{\circledR}$ & GCGCA XI ACGGGACGGAAAGAC & \\
\hline \multirow{3}{*}{$\begin{array}{l}\text { Chlamydiales } 16 \mathrm{~S} \\
\text { rRNA gene }\end{array}$} & panCh-Fwd & CCGCCAACACTGGGACT & \multirow[t]{3}{*}{ *[16,17] } \\
\hline & panCh-Rev & GGAGTTAGCCGGTGCTTCTTTAC & \\
\hline & panCh-Probe & FAM-CTACGGGAGGCTGCAGTCGAGAATC-BHQ1 & \\
\hline \multirow{3}{*}{$\begin{array}{l}\text { Acanthamoeba spp. } \\
\text { 18S rRNA gene }\end{array}$} & Acan Fw & CCAGATCGTTTACCGTGAA & \multirow[t]{3}{*}{${ }^{*}[19]$} \\
\hline & Acan $\mathrm{Rv}$ & TATTAATGCCCCCAACTATCC & \\
\hline & Acan probe & FAM-TCTGCCACCGAATACATTAGCATGG-Iowa black FQ & \\
\hline \multirow{3}{*}{$\begin{array}{l}\text { Vahlkampfiidae spp. } \\
\text { 18S rRNA gene }\end{array}$} & Vahl Fw & GTATAGTCGCAAGACCGAAAC & \multirow[t]{3}{*}{${ }^{*}[20]$} \\
\hline & Vahl Rv & CAAGACAGATCACTCCACGA & \\
\hline & Vahl probe & Cy5-GGGAAACTCACCAGGTCAGGACAC-Iowa black FQ & \\
\hline \multirow{3}{*}{$\begin{array}{l}\text { Vermamoeba vermiformis } \\
\quad 18 \mathrm{~S} \text { rRNA gene }\end{array}$} & Verm Fw & TACGAGGTCAGGACACTGTG & \multirow[t]{3}{*}{ *[21] } \\
\hline & Verm Rv & ACCATCCGGAGTTCTCG & \\
\hline & Verm probe & JOE-AATTCCTAGTAGGCGCGAGTCATCAA-Iowa black FQ & \\
\hline
\end{tabular}




\subsection{Amoeba PCR}

All samples giving a signal in PanChlamydiales-PCR were studied further by PCR methods targeting free-living amoeba, the natural hosts of CRB. The primers and probes used for amoeba detection are presented in Table 1 [19-21]. The PCR reactions (total volume $25 \mu \mathrm{L}$ ) contained $12.5 \mu \mathrm{L}$ Maxima Probe/ROX qPCR Master Mix (2X) (Thermo Scientific, Waltham, MA, USA), and $5 \mu \mathrm{L}$ template DNA. For Acanthamoeba and Vahlkampfiidae (including Naegleria spp.), a duplex PCR reaction, $500 \mathrm{nM}$ of primers and $250 \mathrm{nM}$ probe were used. For Vermamoeba PCR reaction, $200 \mathrm{nM}$ of both primers and probe were used. PCR was performed with 7500 Real-Time PCR system (Applied Biosystems). The cycling conditions were $95^{\circ} \mathrm{C}$ for $10 \mathrm{~min}$ and 45 cycles of $95^{\circ} \mathrm{C}$ for $15 \mathrm{~s}$ and $60{ }^{\circ} \mathrm{C}$ for $1 \mathrm{~min}$.

\subsection{Sequencing and Phylogeny}

The pan-Chlamydiales qPCR amplicons were purified by using an Illustra ExoProStar 1-Step kit (GE Healthcare, Buckinghamshire, United Kingdom) according to the manufacturer's instructions. Both the forward and reverse strands of the PCR products were sequenced by using primers panFseq and panRseq [16] in the sequencing unit of the Institute for Molecular Medicine Finland. Sequences were compared to the known sequences in the NCBI database by BLAST analysis. For family level classification, the first established CRB strain of the BLAST hit list was determined, and if the sequence identity was $\geq 90 \%$, the two sequences were considered as members of the same CRB family $[17,18,22]$. The Verrucomicrobium spinosum sequence was included as an outgroup (GenBank accession number X90515), as it was used previously as an outgroup for all Chlamydiales [23]. We constructed a Bayesian posterior-probability consensus tree using a total chain length of 1,100,000 and a burn-in length of 11,000. The analysis was carried out by using Geneious software [24]. Sequences were aligned by using the MUSCLE plug-in [25], and Bayesian analysis was done with the MrBayes plug-in [26].

\section{Results}

\subsection{Detection of Chlamydia pneumoniae}

All samples were studied by a PCR based method amplifying Mycoplasma pneumoniae and Chlamydia pneumoniae [14]. Of the 278 samples, only one $(1 / 278,0.4 \%)$ was shown to contain Chlamydia pneumoniae DNA. This sample was from a patient in group 1 (who sought health care consultation with signs and symptoms suggestive of M. pneumoniae infection) (sample ID 1410, Table 2).

Table 2. Samples containing Chlamydiales DNA.

\begin{tabular}{|c|c|c|c|c|c|c|c|c|}
\hline $\begin{array}{c}\text { Sample } \\
\text { ID }\end{array}$ & $\begin{array}{c}\text { Age } \\
\text { (Years) }\end{array}$ & Gender & GROUP * & School ** & & Symptoms & Chlamydiales Family & Other \\
\hline 1410 & 8 & male & 1 & & yes & & Chlamydiaceae & C. pneumoniae PCR+ \\
\hline 1563 & 10 & female & 1 & & yes & & Parachlamydiaceae & M. pneumoniae $\mathrm{PCR}+, \mathrm{IgM}+$ \\
\hline 1385 & 6 & male & 1 & & yes & & Parachlamydiaceae & \\
\hline 1463 & 7 & female & 1 & & yes & & Parachlamydiaceae & M. pneumoniae IgM+ \\
\hline 1510 & 7 & male & 1 & & yes & & Parachlamydiaceae & \\
\hline V15 & 13 & female & 2 & 1 & NA & & Parachlamydiaceae & \\
\hline V45 & 14 & female & 2 & 1 & yes & fever, cough, rhinitis & Parachlamydiaceae & \\
\hline V8 & 13 & male & 2 & 1 & NA & & Parachlamydiaceae & M. pneumoniae PCR+ \\
\hline V48 & 14 & female & 2 & 1 & yes & fever, cough, rhinitis & Parachlamydiaceae & \\
\hline V57 & 14 & male & 2 & 1 & NA & & Parachlamydiaceae & \\
\hline V62 & 9 & male & 2 & 2 & yes & cough, rhinitis & Parachlamydiaceae & \\
\hline V71 & 9 & male & 2 & 2 & no & & Parachlamydiaceae & \\
\hline V104 & 12 & male & 2 & 2 & yes & cough, rhinitis & Parachlamydiaceae & \\
\hline V111 & 17 & female & 2 & 3 & yes & fever, cough, rhinitis & Parachlamydiaceae & \\
\hline V114 & 14 & female & 2 & 1 & NA & & Parachlamydiaceae & \\
\hline $\mathrm{K} 4$ & 9 & female & 2 & 4 & yes & fever, cough & Parachlamydiaceae & \\
\hline V230 & 17 & female & 2 & 3 & NA & & Parachlamydiaceae & \\
\hline V74 & 9 & male & 2 & 2 & yes & fever & Criblamydiaceae & \\
\hline
\end{tabular}


Table 2. Cont.

\begin{tabular}{|c|c|c|c|c|c|c|c|c|}
\hline $\begin{array}{c}\text { Sample } \\
\text { ID }\end{array}$ & $\begin{array}{c}\text { Age } \\
\text { (Years) }\end{array}$ & Gender & GROUP * & School ** & & Symptoms & Chlamydiales Family & Other \\
\hline K13 & 10 & male & 2 & 4 & yes & fever, cough, rhinitis & Criblamydiaceae & \\
\hline V211 & 11 & female & 2 & 2 & yes & rhinitis & Simkaniaceae & \\
\hline V42 & 14 & female & 2 & 1 & yes & cough, rhinitis & Unclassified & \\
\hline V49 & 14 & male & 2 & 1 & yes & fever & Unclassified & \\
\hline
\end{tabular}

\subsection{Detection of Chlamydiales DNA}

Altogether 22/278 (7.9\%) samples gave a positive result by PanChlamydiales PCR. Of these 22 samples, 5 were from symptomatic individuals that belonged to the group 1 (sought health care consultation). Of the 17 Chlamydiales DNA-positive samples in group 2 (school screening), 11 were from individuals with respiratory symptoms (rhinitis and/or cough and/or fever) and one from those without such symptoms ( $9.8 \%$ and $6.7 \%$, respectively). However, the interpretation is limited by the small number of those reporting no symptoms $(n=15)$. No information on possible respiratory symptoms or fever was available from five individuals with Chlamydiales DNA.

As expected, the specimen positive for C. pneumoniae DNA (ID 1410, group 1) was amplified also by PanChlamydiales primers and was included in the set of 22 positive specimens. Of these 22 samples, only two contained also M. pneumoniae DNA (sample no V8, group 2 and 1563, group 1). In addition, one individual had serological evidence of a recent M. pneumoniae infection (ID 1463, group 1) (Table 2).

\subsection{Amoeba PCR}

Amoebal DNA (Acanthamoeba, Vahlkampfiidae, including Naegleria, or Vermamoeba) was not detected in any of the PanChlamydiales-positive samples (0/22).

\subsection{Sequencing and Phylogeny}

By sequence analysis, 16 (72.7\%) of the 22 samples containing Chlamydiales DNA were classified as members of the family Parachlamydiaceae. By this method, sequences belonging to Criblamydiaceae family were identified in two $(9.1 \%)$ and to Simkaniaceae family in one $(4.5 \%)$ of the 22 respiratory samples. One sample contained a sequence $(4.4 \%)$ that was classified as C. pneumoniae: by BLAST analysis, the DNA sequence of the PanChlamydiales-PCR amplicon showed 99\% identity with the Chlamydia pneumoniae genome assembly YK41, GenBank no LN849050. The same sample was identified as positive by the Chlamydia pneumoniae-specific PCR. In two (9.1\%) samples, the DNA sequences were shown to belong to Chlamydiales order, but remained unclassified on family level.

In the phylogenetic tree, the $C$. pneumoniae sequence grouped together with the reference sequences from the Chlamydiaceae family. Interestingly, the two unclassified Chlamydiales sequences (V49 and V42) grouped together in the phylogenetic tree, and formed a cluster separate from the Chlamydiaceae family (Figure 1). This might indicate a previously undescribed Chlamydiales bacteria, although the support for this clade is rather low (72\%). The two individuals were both from the same school (Virolahti Middle School) and same class (a 14-year old male and a 14-year old female). The boy was reported to have fever and the girl had cough and rhinitis. Some other sequences, such as K4 and V111 may also be examples of novel species, with high support for the clade $(94 \%)$. The C. pneumoniae specific-PCR did not amplify these specimens, although the internal control was amplified. 


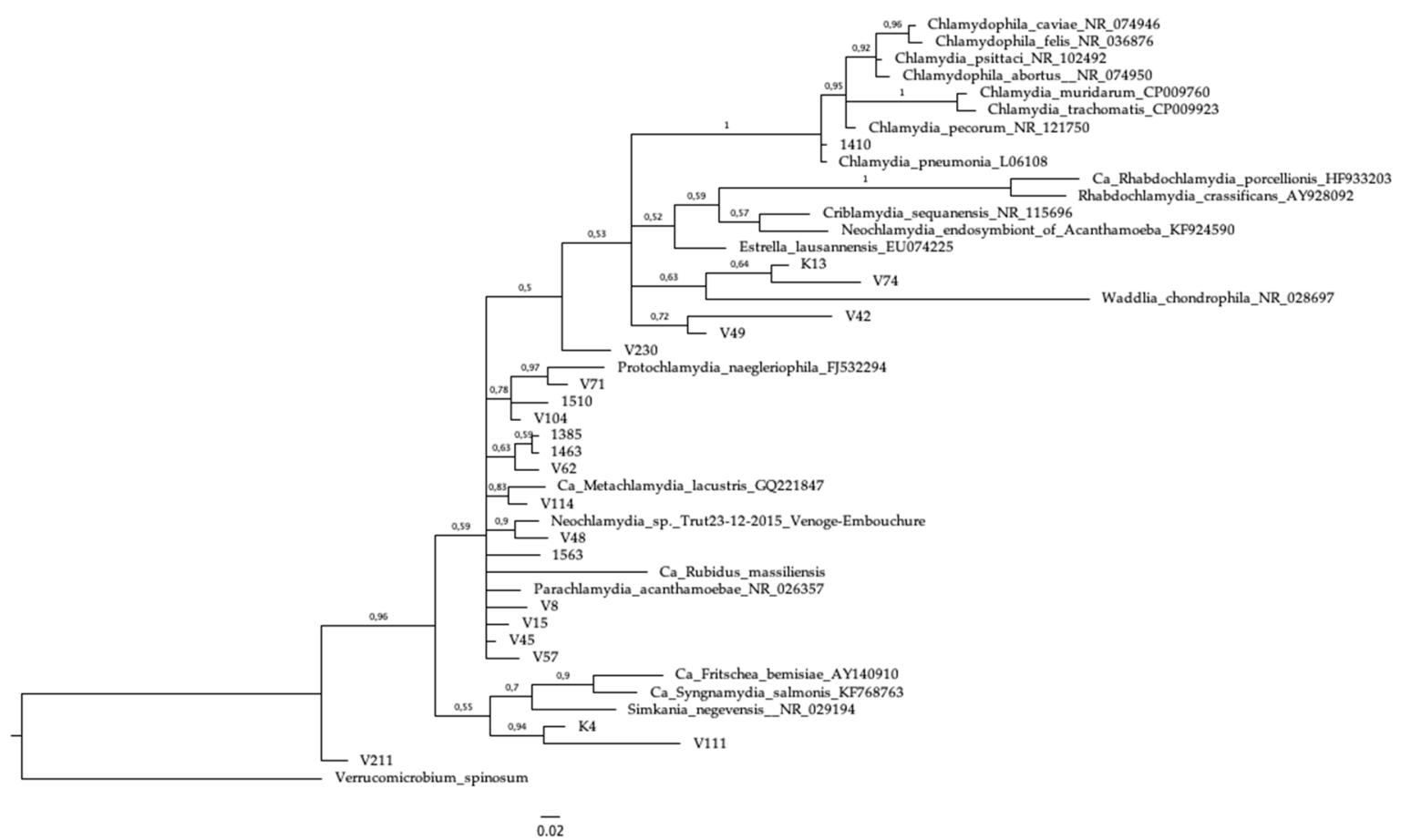

Figure 1. Bayesian posterior probability tree of the sequences in this study along with reference sequences and Verrucomicrobium spinosum as an outgroup to root the tree. Some clades are well resolved whereas some are weakly, probably due to short sequence length. The scale bar represents $2 \%$ genetic divergence.

\section{Discussion}

Starting in 2017, an increasing incidence of respiratory infections, including pneumonias, were observed among school-children and their family members in Kymenlaakso region in Southeastern Finland. Testing of respiratory swab and serum samples from 327 individuals by a PCR method [14] and serology, respectively, provided evidence of Mycoplasma pneumoniae infection in 19\% of the school-children and their family members [13]. To further investigate the cluster of respiratory infections, respiratory tract swabs from 96 of these individuals (mainly from children) and additional 182 swabs collected from children attending schools in the area were amplified by Chlamydiales-PCR.

With the PanChlamydiales-PCR assay [16], we detected Chlamydiales DNA in 22 respiratory samples. By subsequent sequence analysis, only one was shown to belong to the Chlamydiaceae family, and it was further classified as C. pneumoniae, an established cause of respiratory infections, including atypical pneumonia. The sequencing result was consistent with the C. pneumoniae-positive PCR data strengthening the plausibility of the results obtained with PanChlamydiales-PCR and sequencing. Among specimens collected during this outbreak, neither Chlamydia psittaci nor Chlamydia caviae, which recently have been reported to cause pneumonia in humans, i.e., due to exposure to ill guinea pigs, were seen [27-29]. Interestingly, however, two of the sequences that, by the scheme used, remained as "unclassified", bunched together in the phylogenetic analysis (sequences V42 and V49; Figure 1) and might represent a novel type of Chlamydia-related bacteria. Both samples were from symptomatic 14-year-old individuals, class mates (male and female) from the same school.

Parachlamydia acanthamoebae is the most studied member of the chlamydia-related bacteria, including several studies presenting evidence supporting its role as a CAP causing pathogen $[4,5,30,31]$. In vitro, Parachlamydia is indeed able to enter and grow in cells present in respiratory tract, macrophages [32] and pneumocytes [33]. Majority of the chlamydiales sequences within our respiratory tract specimens (73\%) were taxonomically classified as members of the Parachlamydiaceae family, which is in concordance with earlier studies. Casson et al. set up a real-time PCR method specific for Parachlamydia acanthamoebae, and as they applied it to 39 nasopharyngeal aspirates obtained from children with respiratory syncytial 
virus-negative bronchiolitis, they found 13/39 to contain P. acanthamoebae DNA [34]. However, only one of their results could be confirmed by sequencing. Lienard et al. used the PanChlamydiales PCR and subsequent sequence analysis and detected Parachlamydiaceae DNA in 26/422 (6.2\%) nasopharyngeal swab samples taken from hospitalized children (between 1-15 years old) [16]. This is in good agreement with our data, as in our study the prevalence of parachlamydiaceae DNA was $5.8 \%$ among respiratory specimens collected from patients between 6-17 years old. In our study $63 \%$ of the samples containing Parachlamydiaceae DNA were from individuals with respiratory symptoms and/or fever. In the study by Lienard et al., Parachlamydiaceae DNA was more often detected among patients without $(60 \%)$ than with $(40 \%)$ pneumonia [16]. However, as their group without pneumonia were hospitalized children, they supposedly were not completely asymptomatic. In contrast to these data, among 564 adult patients (median age of 76 years; range 21-101 years) with moderately severe community-acquired pneumonia, oropharyngeal samples were studied again by the PanChlamydiales PCR method, and only one was found to contain Chlamydiales DNA [35,36]. Similarly, in our earlier study on respiratory samples from patients sent for C. pneumoniae and M. pneumoniae nucleic acid testing, P. acanthamoebae DNA was not detected $(n=102)$ [11]. However, Rhabdochlamydia spp. DNA was detected in $16 / 136(12 \%)$ of samples studied. The median age of these Rhabdochlamydia spp. positive patients was 52 (range 11-72). Thus, the results may reflect a difference among the study populations (adults vs. adolescents), or endemic/epidemic outbreak(s) of different members of Chlamydiales order.

There are no general treatment recommendations for conditions associated with P. acanthamoeabae. The antimicrobial susceptibility of Parachlamydiaceae, tested in amoebae, was similar to that of other Chlamydiales, and treatment with macrolides was recommended for parachlamydial pneumonia [37]. As macrolides are also included in the treatment options of pneumonia due to M. pneumoniae, most likely also the individuals with P. acanthamoebae and other Chlamydiales bacteria benefitted from such therapy.

Even today in as many as 50\% of the cases the microbe causing pneumonia remains unidentified. For example, as pointed out by Polkinghorne et al. [27], there is an increasing number of reports on $\mathrm{CAP}$ cases caused by bacteria belonging in the genus Chlamydia that thus far have been considered solely animal pathogens, i.e., Chlamydia caviae. In addition to members of chlamydiaceae, a wide range of the newly detected chlamydia-related bacteria have been associated with respiratory symptoms including pneumonia. This study further confirms that Parachlamydiaceae can be included in the list of potential agents causing atypical CAP in children and adolescents.

Author Contributions: Conceptualization, K.H. and M.P.; methodology, K.H. and M.P.; analysis, K.H., E.J.V., S.K., M.P.; investigation, R.P.; resources, R.P.; data curation, K.H., S.K., R.P.; writing—original draft preparation, K.H.; writing-review and editing, K.H., S.K., T.N., H.S., E.J.V., L.M., R.P., and M.P.; visualization, K.H. and E.J.V.; project administration, K.H. and M.P.; funding acquisition, H.S. and M.P.

Funding: This research was funded by Helsinki University Hospital, and Academy of Finland, grant number 1285975.

Acknowledgments: We thank Anu Kaitonen for technical assistance.

Conflicts of Interest: The authors declare no conflict of interest. The funders had no role in the design of the study; in the collection, analyses, or interpretation of data; in the writing of the manuscript, or in the decision to publish the results.

\section{References}

1. Pillonel, T.; Bertelli, C.; Greub, G. Environmental Metagenomic Assemblies Reveal Seven New Highly Divergent Chlamydial Lineages and Hallmarks of a Conserved Intracellular Lifestyle. Front. Microbiol. 2018, 9, 79. [CrossRef] [PubMed]

2. Corsaro, D.; Venditti, D. Diversity of the parachlamydiae in the environment. Crit. Rev. Microbiol. 2006, 32, 185-199. [CrossRef] [PubMed]

3. Taylor-Brown, A.; Vaughan, L.; Greub, G.; Timms, P.; Polkinghorne, A. Twenty years of research into Chlamydia-like organisms: A revolution in our understanding of the biology and pathogenicity of members of the phylum Chlamydiae. Pathog. Dis. 2015, 73, 1-15. [CrossRef] 
4. Pilloux, L.; Casson, N.; Sommer, K.; Klos, A.; Stehle, J.C.; Pusztaszeri, M.; Greub, G. Severe pneumonia due to Parachlamydia acanthamoebae following intranasal inoculation: A mice model. Microbes Infect. 2015, 17, 755-760. [CrossRef]

5. Greub, G.; Boyadjiev, I.; La Scola, B.; Raoult, D.; Martin, C. Serological hint suggesting that Parachlamydiaceae are agents of pneumonia in polytraumatized intensive care patients. Ann. N. Y. Acad. Sci. 2003, 990, 311-319. [CrossRef]

6. Verweij, S.P.; Kebbi-Beghdadi, C.; Land, J.A.; Ouburg, S.; Morre, S.A.; Greub, G. Waddlia chondrophila and Chlamydia trachomatis antibodies in screening infertile women for tubal pathology. Microbes Infect. 2015, 17, 745-748. [CrossRef]

7. Baud, D.; Regan, L.; Greub, G. Emerging role of Chlamydia and Chlamydia-like organisms in adverse pregnancy outcomes. Curr. Opin. Infect. Dis. 2008, 21, 70-76. [CrossRef]

8. Haider, S.; Collingro, A.; Walochnik, J.; Wagner, M.; Horn, M. Chlamydia-like bacteria in respiratory samples of community-acquired pneumonia patients. FEMS Microbiol. Lett. 2008, 281, 198-202. [CrossRef] [PubMed]

9. Goy, G.; Croxatto, A.; Posfay-Barbe, K.M.; Gervaix, A.; Greub, G. Development of a real-time PCR for the specific detection of Waddlia chondrophila in clinical samples. Eur. J. Clin. Microbiol. Infect. Dis. 2009, 28, 1483-1486. [CrossRef] [PubMed]

10. Heiskanen-Kosma, T.; Paldanius, M.; Korppi, M. Simkania negevensis may be a true cause of community acquired pneumonia in children. Scand. J. Infect. Dis. 2008, 40, 127-130. [CrossRef]

11. Niemi, S.; Greub, G.; Puolakkainen, M. Chlamydia-related bacteria in respiratory samples in Finland. Microbes Infect. 2011, 13, 824-827. [CrossRef]

12. Lamoth, F.; Jaton, K.; Vaudaux, B.; Greub, G. Parachlamydia and Rhabdochlamydia: Emerging agents of community-acquired respiratory infections in children. Clin. Infect. Dis. 2011, 53, 500-501. [CrossRef]

13. Kurkela, S.; Puolakkainen, M.; Hokynar, K.; Nieminen, T.; Saxen, H.; Mannonen, L.; Pietikäinen, R. Mycoplasma pneumoniae outbreak, Southeastern Finland, 2017-2018: Molecular epidemiology and laboratory diagnostic lessons. Eur. J. Clin. Microbiol. Infect. Dis. 2019, under review.

14. Nummi, M.; Mannonen, L.; Puolakkainen, M. Development of a multiplex real-time PCR assay for detection of Mycoplasma pneumoniae, Chlamydia pneumoniae and mutations associated with macrolide resistance in Mycoplasma pneumoniae from respiratory clinical specimens. Springerplus 2015, 4, 684. [CrossRef]

15. Mannonen, L.; Kamping, E.; Penttila, T.; Puolakkainen, M. IFN-gamma induced persistent Chlamydia pneumoniae infection in HL and Mono Mac 6 cells: characterization by real-time quantitative PCR and culture. Microb. Pathog. 2004, 36, 41-50. [CrossRef] [PubMed]

16. Lienard, J.; Croxatto, A.; Aeby, S.; Jaton, K.; Posfay-Barbe, K.; Gervaix, A.; Greub, G. Development of a new chlamydiales-specific real-time PCR and its application to respiratory clinical samples. J. Clin. Microbiol. 2011, 49, 2637-2642. [CrossRef]

17. Hokynar, K.; Sormunen, J.J.; Vesterinen, E.J.; Partio, E.K.; Lilley, T.; Timonen, V.; Panelius, J.; Ranki, A.; Puolakkainen, M. Chlamydia-Like Organisms (CLOs) in Finnish Ixodes ricinus Ticks and Human Skin. Microorganisms 2016, 4, 28. [CrossRef]

18. Everett, K.D.; Bush, R.M.; Andersen, A.A. Emended description of the order Chlamydiales, proposal of Parachlamydiaceae fam. nov. and Simkaniaceae fam. nov., each containing one monotypic genus, revised taxonomy of the family Chlamydiaceae, including a new genus and five new species, and standards for the identification of organisms. Int. J. Syst. Bacteriol. 1999, 49, 415-440.

19. Qvarnstrom, Y.; Visvesvara, G.S.; Sriram, R.; da Silva, A.J. Multiplex real-time PCR assay for simultaneous detection of Acanthamoeba spp., Balamuthia mandrillaris, and Naegleria fowleri. J. Clin. Microbiol. 2006, 44, 3589-3595. [CrossRef] [PubMed]

20. Scheikl, U.; Tsao, H.F.; Horn, M.; Indra, A.; Walochnik, J. Free-living amoebae and their associated bacteria in Austrian cooling towers: A 1-year routine screening. Parasitol. Res. 2016, 115, 3365-3374. [CrossRef]

21. Kuiper, M.W.; Valster, R.M.; Wullings, B.A.; Boonstra, H.; Smidt, H.; van der Kooij, D. Quantitative detection of the free-living amoeba Hartmannella vermiformis in surface water by using real-time PCR. Appl. Environ. Microbiol. 2006, 72, 5750-5756. [CrossRef] [PubMed]

22. Pillonel, T.; Bertelli, C.; Salamin, N.; Greub, G. Taxogenomics of the order Chlamydiales. Int. J. Syst. Evol. Microbiol. 2015, 65, 1381-1393. [CrossRef] [PubMed] 
23. Hokynar, K.; Vesterinen, E.J.; Lilley, T.M.; Pulliainen, A.T.; Korhonen, S.J.; Paavonen, J.; Puolakkainen, M. Molecular Evidence of Chlamydia-Like Organisms in the Feces of Myotis daubentonii Bats. Appl. Environ. Microbiol. 2017, 83, 2. [CrossRef] [PubMed]

24. Kearse, M.; Moir, R.; Wilson, A.; Stones-Havas, S.; Cheung, M.; Sturrock, S.; Buxton, S.; Cooper, A.; Markowitz, S.; Duran, C.; et al. Geneious Basic: An integrated and extendable desktop software platform for the organization and analysis of sequence data. Bioinformatics 2012, 28, 1647-1649. [CrossRef] [PubMed]

25. Edgar, R.C. MUSCLE: A multiple sequence alignment method with reduced time and space complexity. BMC Bioinform. 2004, 5, 113. [CrossRef] [PubMed]

26. Huelsenbeck, J.P.; Ronquist, F. MRBAYES: Bayesian inference of phylogenetic trees. Bioinformatics 2001, 17, 754-755. [CrossRef] [PubMed]

27. Polkinghorne, A.; Borel, N.; Heijne, M.; Pannekoek, Y. New evidence for domesticated animals as reservoirs of Chlamydia-associated community-acquired pneumonia. Clin. Microbiol. Infect. 2018, 25, 131-132. [CrossRef]

28. Ramakers, B.P.; Heijne, M.; Lie, N.; Le, T.N.; van Vliet, M.; Claessen, V.P.J.; Tolsma, P.J.P.; De Rosa, M.; Roest, H.I.J.; Vanrompay, D.; et al. Zoonotic Chlamydia caviae Presenting as Community-Acquired Pneumonia. N. Engl. J. Med. 2017, 377, 992-994. [CrossRef]

29. Van Grootveld, R.; Bilsen, M.P.; Boelsums, T.L.; Heddema, E.R.; Groeneveld, G.H.; Gooskens, J.; de Boer, M.G.J. Chlamydia caviae Causing Community-Acquired Pneumonia: An Emerging Zoonosis. Vector-Borne Zoonotic Dis. 2018, 18, 635-637. [CrossRef]

30. Marrie, T.J.; Raoult, D.; La Scola, B.; Birtles, R.J.; de Carolis, E.; Canadian Community-Acquired Pneumonia Study Group. Legionella-like and other amoebal pathogens as agents of community-acquired pneumonia. Emerg. Infect. Dis. 2001, 7, 1026-1029. [CrossRef]

31. Greub, G.; Berger, P.; Papazian, L.; Raoult, D. Parachlamydiaceae as rare agents of pneumonia. Emerg. Infect. Dis. 2003, 9, 755-756. [CrossRef]

32. Greub, G.; Mege, J.L.; Raoult, D. Parachlamydia acanthamoebae enters and multiplies within human macrophages and induces their apoptosis [corrected]. Infect. Immun. 2003, 71, 5979-5985. [CrossRef]

33. Casson, N.; Medico, N.; Bille, J.; Greub, G. Parachlamydia acanthamoebae enters and multiplies within pneumocytes and lung fibroblasts. Microbes Infect. 2006, 8, 1294-1300. [CrossRef] [PubMed]

34. Casson, N.; Posfay-Barbe, K.M.; Gervaix, A.; Greub, G. New diagnostic real-time PCR for specific detection of Parachlamydia acanthamoebae DNA in clinical samples. J. Clin. Microbiol. 2008, 46, 1491-1493. [CrossRef] [PubMed]

35. Garin, N.; Hugli, O.; Genne, D.; Greub, G. Lack of Chlamydia-related bacteria among patients with community-acquired pneumonia. New Microbes New Infect. 2015, 8, 164-165. [CrossRef] [PubMed]

36. Garin, N.; Genne, D.; Carballo, S.; Chuard, C.; Eich, G.; Hugli, O.; Lamy, O.; Nendaz, M.; Petignat, P.A.; Perneger, T.; et al. beta-Lactam monotherapy vs beta-lactam-macrolide combination treatment in moderately severe community-acquired pneumonia: A randomized noninferiority trial. JAMA Intern. Med. 2014, 174, 1894-1901. [CrossRef]

37. Vouga, M.; Diabi, H.; Boulos, A.; Baud, D.; Raoult, D.; Greub, G. Antibiotic susceptibility of Neochlamydia hartmanellae and Parachlamydia acanthamoebae in amoebae. Microbes Infect. 2015, 17, 761-765. [CrossRef] [PubMed]

(C) 2019 by the authors. Licensee MDPI, Basel, Switzerland. This article is an open access article distributed under the terms and conditions of the Creative Commons Attribution (CC BY) license (http://creativecommons.org/licenses/by/4.0/). 